\title{
On an Anomalous Piece of Scientology Ephemera: The Booklet Scientology and the Bible ${ }^{1}$
}

STEFANO BIGLIARDI

Al Akhawayn University

\begin{abstract}
The article scrutinises the booklet Scientology and the Bible (1967), reconstructing the historical circumstances of its publication as well as analysing its potential for interreligious dialogue.
\end{abstract}

Keywords: Scientology; Scientology and Christianity; Scientology and the Bible

The teachings on which Scientology is based are contained in a wealth of publications directly produced, or strictly supervised, by its founder Lafayette Ronald Hubbard (1911-1986), who undoubtedly was endowed with remarkable creativity and productivity. While Scientology is coming under increasing scrutiny by NRM scholars, who try not only to study Scientology from a sociological perspective but also to scrutinise its theories and beliefs, Hubbard's tremendous corpus is examined accordingly and in detail, revealing conceptual shifts over time as well as analogies between Hubbard's narrative production and Scientology's canon.

A relatively unexplored subfield in this regard is Scientology's publications co-authored with Hubbard or even produced by some Scientologists other than the founder, which currently have second-class status and are less prominent, if non-existent, in many churches, since Hubbard's writings are central and it is claimed that they are conserved and transmitted without change or variation. An especially intriguing case is the booklet Scientology and the Bible, which dates from 1967. This small publication appeared during a

1 I would like to express deep gratitude to the anonymous reviewers, to Liesl Drew who proofread the first and the second version of the present article, and of course to all the informants. As always, fellow scholars Donald Westbrook and Bernard Doherty provided me with precious materials, contacts, and insights for which I am most thankful. Bernard inspired the title of the article by defining Scientology and the Bible 'a fascinating piece of Scientology ephemera' in a 12 March 2015 message in the mailing list New Religious Movements (NRM 7826). The research upon which the article is based was conducted while I was in receipt of generous support from FIIRD in Geneva. I dedicate this article to the students and colleagues who attended the AUI Interfaith Alliance Club Dinner Discussion 'Just a Shade above Clear: Scientology and Interreligious Dialog' on Monday 26 September 2016. 
particularly problematic time for Scientology and is credited to seven authors or compilers, one of whom is reported to have died in the year prior to its publication. The booklet addresses the analogies between Scientology and Christianity and displays interesting traits both as to its structure and content.

The analogies between Scientology and other religions, as well as Scientology's approach towards other faiths and beliefs, have become increasingly relevant with globalisation, the church's expansion worldwide, and its increasing aspiration to be recognised not only as a religion in its own right but also as a credible interlocutor in interfaith dialogue. The present article is an attempt at contextualising and analysing Scientology and the Bible. The first section presents Scientology's most general teachings, with some emphasis on its theory of knowledge and of God. The second discusses the question of whether Scientology should be considered a genuine religion. The third focuses on Scientology's stance towards Christianity and Jesus Christ. The fourth touches on the role of language in Hubbard's theological writings. The fifth presents the events that marked Scientology's history around 1967. The sixth examines Scientology and the Bible by focusing on its structure, declared sources, and concepts. The seventh contains information concerning the booklet's production and circulation provided by several informants. In the eighth I try to reconstruct, in the light of the previous sections, the booklet's Sitz im Leben, i.e. its role at the time of its publication and the possible reasons that prompted its production. The conclusions contain some hypotheses as to why the booklet is no longer in use, despite Scientology's concern for interreligious recognition.

Some observations should be added about what prompted me to write the present essay and the method followed in the investigations that provided the material for the seventh section, which is instrumental for the conclusions drawn. I first came across Scientology and the Bible while conducting a simple internet search for the terms 'Scientology' and 'Bible', in the context of wider research concerning Hubbard's discussions of the Abrahamic religions. The booklet was (and still is) mentioned and displayed in several discussion groups with disparaging tones. It struck me as intriguing by virtue of three elements: the enigmatic cover illustration, its multiple authorship, and its subject. I soon realised that precise and reliable data about its production and circulation were lacking, both in academic literature and, more generally, on the web. Clearly, the booklet was not referenced in current Scientology, official web pages, and texts underscoring the movement's commitment to interreligious dialogue, and this was paradoxical. Indeed, there was very little to hold on to beyond the derogatory remarks. I decided to produce the academic paper I would have liked to have read after I first encountered Scientology and the Bible, i.e. an 
essay reconstructing the circumstances in which the booklet was written and circulated, but also assessing its content: how was the booklet structured, and was it well-argued, clear, and convincing? What could be guessed about the authors' competence concerning the Bible? What could be its present value in Scientology's discussion of interreligious issues? To answer such questions I decided to put derogatory comments within brackets and to read the booklet with an open mind, i.e. by charitably assuming it had been the result of a genuine (albeit possibly amateurish) theological effort by its authors.

Given that at the outset there was little information on the circumstances of the booklet's production, its history had to be built from scratch based on the accounts of informants. A special problem emerged as to potential informants. In the study of Scientology they can be roughly divided into exmembers and members (and obviously in this case, they had to be selected among long-serving ones in both groups). Given the extremely controversial character of Scientology, any response to scholarly queries, including those about factual matters such as those in which I was interested, is likely to be formulated with a certain bias. Disgruntled ex-members, although factually well-informed, might be eager to belittle both the relevance of the booklet as well as the very initiative of writing it, and so on. Scientologists interested in enhancing the movement's reputation might overstate the relevance of the work, but also pass over 'embarrassing' circumstances connected to the fact that (as I realised at an early stage) the booklet never became a central publication in Scientology's canon, and so on. ${ }^{2}$ It should also be remarked

2 Similar observations regarding bias and undertones hold for written sources in the form of books and articles. Jon Atack, Bent Corydon, and Russell Miller, whose monographs are referenced in the present essay, all fall under the (broad) category of authors hostile to Scientology, as well as journalist Tony Ortega. When reading Corydon \& Hubbard Jr. 1987 we must bear in mind that Hubbard Jr. (Ronald DeWolf), on whose memoirs and interviews the book is based according to Corydon (himself a former high-ranking Scientologist), made a retraction of his co-authorship prior to the book's official release that was nevertheless indicated in the first edition (Hubbard Jr.'s official complaint to the Federal District Court of New Jersey available at: https://upload.wikimedia.org/wikipedia/commons/7/73/Ronald_Edward_Dewolf_01_ July_1987.pdf). All such caveats considered, these works still constitute a useful starting point for a discussion of Hubbard/Scientology given the wealth of detailed first-hand information they contain, in particular about episodes that have yet to be examined academically in great detail (as is the case, for example, with Hubbard's forays in South Africa and Rhodesia). That a work is generally hostile does not necessarily mean it is not well-researched. Atack (who is also a former, long-serving Scientologist) especially supports his claims with a system of references that places his monograph on a par with academic texts, and the gist of historical reconstruction he and Corydon and Miller present (i.e. the specific facts they recall) is also discussed or presented in the same terms in more academic historical works (for example, those of Roy Wallis or Hugh Urban). In my opinion awareness of different (negative) biases should 
that secrecy plays an important role in Scientology (which is, as we will see, initiatory in character), that the movement's relationship with researchers has undergone a process of détente only in relatively recent times, and that a single member, although eager to interact with a researcher, might at the same time be afraid of being reproached by higher-ranking members for having disclosed too much information.

The variables involved are subtle and numerous. To this we should add general and commonsensical caveats concerning anybody's capacity to accurately recall events that occurred half a century ago. Well aware of these challenges, I decided to consult with representatives of both groups in order to strike a balance, given that they had served in the movement for long enough to potentially hold relevant, first-hand information. I thus made enquiries of three prominent ex-members (two based in the US, one in the UK), as well as with three high-ranking Scientologists based respectively in the US, the UK, and Australia. Of the former, both US-based ex-members came up with articulate answers. Of the latter, only my Australian informant was able to help, yet did so thoroughly, even being in a position to exchange information with one of the booklet's authors.

I formulated my question as neutrally as possible: 'Do you happen to recall any information concerning the production and circulation of the 1967 booklet Scientology and the Bible?' I did not explicitly ask for personal evaluations of its content and function, although of course I expected the informants to add their opinion, which eventually happened. I decided to act very tactfully and respectfully and to take all my informants' statements at face value, i.e. not to challenge them on any factual points or opinion (unless they stated blatant contradictions or inaccuracies, which was never the case). In the case of the Australian informant I did not insist on getting directly in touch with the booklet's co-author, nor on obtaining more information than the informant was willing to share. For all these reasons all such information is provided in the form of a direct quotation from my private exchanges. ${ }^{3}$ This Scientologist also preferred to remain anonymous, a

lead to critical discussion and presentation, not to their rejection altogether. It is also highly disputable that academic reconstructions are completely free of any bias or self-censorship, especially considering Scientology's attitude towards investigations of any kind over the past decades. For these reasons I have made extensive mention of historical passages by 'hostile' authors in the present essay. I have principally mentioned passages from such monographs that concern factual information rather than the authors' judgement of Scientology, or in any case passages in which such authors are clearly trying to be as objective as possible (e.g. when Miller criticises the Anderson Report). I also complement such reference with mention of analogous passages in Wallis's and Urban's work (as well as other scholarly sources such as Bernard Doherty's discussion of the Anderson Report) when possible. For a discussion of the sources concerning Scientology (especially the Sea Org) and of their respective biases see also Melton 2001 no. 60.

3 I have selected the parts I deemed relevant. The full texts are in my archives and available to all who are interested. 
wish I respected. ${ }^{4}$ In the light of all such choices and provisos, it is my hope that my readers will still appreciate the information concerning a booklet whose examination started in a sort of vacuum, and that on this basis they will be able to form their own opinion both as to the circumstances of its production and its content.

\section{Dianetics, Scientology, and the concepts of soul and God}

The first nucleus of what are today Scientology's teachings stemmed from what Hubbard presented as his research into the human soul performed after the Second World War, and which he organised into a method called Dianetics (according to Hubbard's explanation from the ancient Greek terms for 'through' and 'knowledge'). Dianetics was first explained in an article appearing in a science fiction magazine in May 1950, and later in an independent volume published that year (Hubbard 1950a; Hubbard 1950b). Dianetics claims that the human mind is impaired by engrams, mnemonic traces of traumatic or negative experiences. The mind is described as mainly divided into two parts. The passive one, where engrams are accumulated, is called reactive, and is opposed to the active, or analytical, mind (CSI 1998, 16). Through a procedure called auditing (from the Latin verb for 'listening'), performed with the help of a device called an E-Meter (Electropsychometer), the engrams can be identified and eliminated, leading to the drastic improvement of a person's potential for action and success (CSI 1998, 33-7).

From the outset Hubbard faced intertwined challenges to the recognition, doctrinal integrity, and financial success of Dianetics. Auditing can recall a session of psychotherapy and Hubbard, at least indirectly if not because of direct reading, was influenced by Freudian ideas. However, when his attempts to obtain the recognition and approval of psychologists and psychiatrists were met with suspicion, contempt, and rebuttal, Hubbard started attacking their disciplines (including medicine more generally) as inhumane and abusive, and they have since remained a principal polemical target of Scientology (Wallis 1976, 23; Urban 2011, 45f.; 59; Kent \& Manca 2014). Furthermore, practitioners began discussing, inventing, and implementing their own variants of Dianetics (Wallis 1976, 81). With a series of practical initiatives, among the most important being the incorporation of three new organisations in December 1953 in

4 I set out not to be influenced by any suggestions from my informants as to the paper's structure and content. The responsibility for how the informants' texts (and their statements in general) are used, especially in the evaluative sections, is entirely mine. 
Camden, NJ (the Church of Scientology, the Church of American Science, and the Church of Spiritual Engineering - Urban 2009, 65), and with the adoption of a new lexicon and narratives, Hubbard began presenting the movement as a religion.

Where doctrine is concerned the birth of Scientology (according to Hubbard from the Latin term for 'knowledge' and the ancient Greek suffix denoting 'study') was marked by Hubbard's encapsulation of Dianetics in a broader conceptual system and narrative. The human soul is defined as thetan (from the ancient Greek letter theta, taken by Hubbard as representing 'life force'), a spiritual unity that goes through a process of successive (human) incarnations (CSI 1998, 17f.). In this enlarged system the engrams are attributed to traumatic experiences, or 'incidents' undergone in lives dating back even millions of years. The thetans' collective vicissitudes are absorbed in a grand narrative whose details are gradually revealed to Scientologists according to their advancement on the path of improvement, defined as the Bridge to Total Freedom, which is walked by successfully performing auditing sessions (CSI 1998, 31, 56). The phases of the advancement through auditing are elaborated in great detail together with hierarchies, auditing procedures, and prices. Before an individual is liberated from the content of the reactive mind he or she is defined as pre-clear. A liberated individual is described as clear (CSI 1998, 37). One of the Bridge's higher stages is defined as Operating Thetan or OT, and is said to be able to control the matter, energy, space, and time (MEST) (CSI $1998,18,37,55,104-9)$ that have otherwise entrapped thetans (since ancestral times, when they forgot their own creative, infinite capacities and thus became entangled in their own creations). Scientology also contains a meticulously numbered taxonomy of emotions called tone levels (Harley and Kieffer 2009, 194f.).

Another relevant theory concerns the eight dynamics or dimensions of survival, perspectives from which thetans can examine themselves and aspire to continue their lives, the eighth being the Supreme Being or God, which is left vague or open (CSI 1998, 22-26). Currently, an official webpage answers the question of whether Scientology has a concept of God as follows: 'Most definitely. In Scientology, the concept of God is expressed as the Eighth Dynamic - the urge toward existence as infinity. This is also identified as the Supreme Being. As the Eighth Dynamic, the Scientology concept of God rests at the very apex of universal survival.' This observation is, however, qualified as follows: 'Unlike religions with Judeo-Christian origins, the Church of Scientology has no set dogma 
concerning God that it imposes on its members. As with all its tenets, Scientology does not ask individuals to accept anything on faith alone.' Full knowledge of God is presented as a supreme achievement on the Bridge: 'Accordingly, only when the Seventh Dynamic (spiritual) is reached in its entirety will one discover and come to a full understanding of the Eighth Dynamic (infinity) and one's relationship to the Supreme Being' (Scientology 2015a).

\section{Dianetics, Scientology, and religion}

Some remarks should be added regarding the shift from Dianetics to Scientology, and the current relationship between the two sets of doctrines. Roy Wallis's ground-breaking monograph (Wallis 1976) described the initial phase as 'cult' and its successor as 'sect'. Although this terminological choice can be considered outdated, Wallis's analysis is correct insofar as the factual reconstruction is concerned, and sufficiently detailed to provide the reader with an overview of the problems related to the Dianetics/Scientology relationship and transition. From a historical perspective the Dianetics movement occurred from 1950 until the incorporation of the first Scientology churches. However, Dianetics and Scientology are separate subjects, the former (Hubbard's mental health system) being presented as the sub-study and forerunner of the latter (Hubbard's applied religious philosophy). The lines between the two are at times blurred; most notably, the language and techniques of Dianetics appear in the OT levels. Wallis writes that the developments in the ideology and organisation

[...] emerged partly as the resolution of a variety of strains and conflicts in the Dianetics community, which existed between Hubbard and other leaders; between Hubbard's desire for a stronger central organization and the amateur groups keen to retain their independence; and between Hubbard and other innovators of theory and practice (Wallis 1976, 77).

Organisational changes and the emergence of new teachings marking Hubbard's movement as new (and specific, as opposed to independent, practice) identity can be considered as two sides of the same coin. Their interaction is open to discussion, and ultimately depends on a judgement of the sincerity of Hubbard's claims. A new teaching such as the existence of previous lives could well stem from his genuine conviction of having made a major 'discovery' that proved controversial and divisive; conversely, emphasis on 
a new teaching might be used as a strong identity marker to differentiate the movement from other groups and test affiliates' loyalty. ${ }^{5}$

The issue of whether Hubbard's discoveries were genuine or instrumental inevitably leads to the important (and enduring) question of whether Scientology is 'really' a religion. Besides having proven decisive in juridical contexts (most notably, when the issue at stake was whether the movement qualified to enjoy a specific fiscal policy) this question is often raised by non-experts. It should also be remembered that, even if one is eager to recognise Scientology as a religion or takes for granted that the answer is in the affirmative, according to Scientology's own narrative it did not stem from a revelation proper, but rather from the 'discoveries' of its founder. In this sense, even by its standards, Scientology is a religion, but a special one. Significantly, Scientology scholar J. Gordon Melton calls one of the chapters of his 2000 monograph 'But is it a religion?' (Melton 2000, 53ff.). Melton recalls in detail both the reasons advanced by the advocates of the position, according to which Hubbard was merely opportunistic in introducing the religious turn, and the reasons Scientology should be considered a religion. Although he is finally inclined to embrace the latter position, he accurately states why Scientology is ultimately a religion sui generis, and he proves able to empathically understand why, above and beyond matters of personal hostility to Hubbard or scepticism towards it, Scientology itself can still be perceived as not completely falling under the category of religion. Having pointed out that Hubbard's 'research', although presented as 'scientific', 'led him quickly into metaphysics and speculation about areas beyond the realm of contemporary science', thus making statements that any scientist would deem religious in character, J. Gordon Melton concludes:

Thus Scientology has found itself in the middle. [...] In developing an organization to embody and perpetuate such a spiritual science, it has created a church, but one that looks unfamiliar to those used to churches and temples which house other more well-known religious groups [...]. Believers and crit-

5 Ex-Scientologist and author Jon Atack provided me with a completely deflationist account of the birth of Scientology, as far as theological and theoretical matters were concerned: ' $[$ Hubbard] sold his rights to Dianetics to Don Purcell [a business man who initially supported him], so he created Scientology. In 1955, Purcell returned the rights, so Hubbard began to use the term again. He later suggested that Dianetics was the "mental science" and Scientology the "spiritual". There is no really consistent definition-Hubbard was an opportunist and reframed his terms to suit the situation. [...] I would simply say that Hubbard first called his subject Dianetics, but adopted the term Scientology after selling the rights to Dianetics' (private communication, 28th December 2015). 
ics agree: the feeling one receives from a Church of Scientology is completely different from a Christian sanctuary or a Buddhist temple (Melton 2000, 58f.).

Melton's remarks help us to understand the complexity of the issues and their nuances. Such questions must be touched on here, although of course they cannot be fully explored. However, the present study adopts a via media, although I am aware that this approach will probably disappoint both Scientologists and Scientology's critics. First, as we have already pointed out, conceptual and organisational shifts are strictly intertwined. In the absence of documents demonstrating with absolute certainty that Hubbard introduced new teachings in a purely instrumental and opportunistic vein, the problem is, to a certain extent, like that of the chicken and the egg. Moreover, we are discussing the relationship (and analogies) between Scientology and Christianity, which everyone considers a proper religion. Precisely for this reason what ultimately matters is that Scientology does contain a theory including concepts (such as God and spirit), narratives (such as the spirit's development and destiny), and prescriptions (such as the behaviour to be embraced in this life) that is shared with, or analogous to, religions in general and Christianity in particular, independently of what prompted Hubbard and his followers to advance these concepts, narratives, and prescriptions. Our preoccupation will be to examine such analogies from a conceptual perspective rather than to guess the reasons for their emergence.

\section{Christian signs and Christ narratives}

Between 1954 and 1959 Scientology emerged as a fully-fledged religion, and established a visual, linguistic, and practical continuity with extant ones. Scientology adopted among its symbols a cross, currently to be seen on major buildings, that shows eight arms. These arms are said to symbolise the above-mentioned eight dynamics. Auditors began wearing white, priestly collars. Similarities emerged in language as well: for example, since auditing started to be called 'pastoral care', auditors were called 'pastors', Scientology seats 'missions', and audited Scientologists 'parishioners'. Hubbard also established ceremonies, such as Sunday services, weddings, and funerals that, analogously to similar ceremonies in other religions, mark both an individual's and the community's existentially most important and most emotion-laden moments (Urban 2011, 66 and Dericquebourg 2009). Again, regardless of the question of whether Hubbard was 'sincere' or not, it seems safe to state that all these traits fulfilled a reassuring function es- 
pecially in the eyes of the US-American public, contributing to the creation of an impression of familiarity.

Over time, and with the emergence of interfaith concerns on a global scale, Scientology strove to present itself as one religious interlocutor among others and on a footing of equality with them. Currently, an official webpage dedicated to the question of Scientology's stance towards Moses, Jesus, Buddha, and Muhammad refers to a lecture given by Hubbard on 3rd June 1955 entitled 'The Hope of Man', in which he stated: 'These great spiritual leaders have been hanged, reviled, misinterpreted, badly quoted, have not been at all comprehended, but nevertheless, they are the hands through which a torch has been handed forward through the centuries.' Among such great spiritual leaders Scientology's founder explicitly names Jesus: 'But what I am telling you is that these people handed on a torch of wisdom, of information, generation to generation. It was handed along geographical routes and one of those geographical routes was the Middle East. And one of the people who handed it on was a man named Moses. And again it was handed on to a man named Christ' (Scientology 2015b).

Indeed, it seems that Hubbard explicitly suggested that the formal acceptance of Jesus Christ was a useful, instrumental strategy in interfaith relationships: "'The way to handle an individual minister of some other church' includes agreeing that Jesus Christ was the Savior of Mankind and that "the Bible is a holy work"' (Urban 2011, 232, n. 33, quoting Hubbard's 'The Scientologist', 1955, Vol. 2, 158).

If one digs more deeply into official statements a more nuanced doctrine seems to emerge that is potentially troubling for Christians. I am not referring to the overall compatibility of Scientology's teachings with Christianity's, but rather to the very figure of Christ and the way in which Hubbard conceptualises it. We should first recall that former members of Scientology who reached the level of Operating Thetan VIII testify that they were assigned to read a posthumous letter by Hubbard in which, inter alia, he referred to Jesus in very unflattering terms:

The historic Jesus was not nearly the sainted figure he has been made out to be. In addition to being a lover of young boys and men, he was given to uncontrollable bursts of temper and hatred (...). It is historic fact and yet man still clings to the ideal, so deep and insidious is the biologic implanting (reported in Ortega 2014). 
The reference to 'implanting' is connected with another doctrine supposedly disclosed at high OT levels, according to which their archenemies filled the thetans in ancestral times with deceiving images or false memories, including those relating to world religions and, more specifically, to Jesus. The former Scientologist and author Jon Atack states in A Piece of Blue Sky: 'In confidential issues, Hubbard dismissed Christian teaching as an "implant". [He] attacked Christianity as an "implant", and said that Christ was a fiction' (Atack 1990, 376, 383).

The Anderson Report (written by Kevin Victor Anderson QC), the result of an official inquiry published in 1965 into the Church of Scientology conducted for the Australian State of Victoria, discusses Scientology's relationship with extant religions and observes: 'In Certainty Magazine, Vol. 5, no. 10, it is written, "Two and a half thousand years ago a handful of clears civilized half a billion people. What if we were all clear. Neither Lord Buddha nor Jesus Christ were OTs according to the evidence. They were just a shade above clear."' (Anderson report, Chapter 27). This passage is also quoted (in reference to the magazine The Ability no. 81, 1959) by Russell Miller in his biography of Hubbard, Bare-Faced Messiah (Miller 1987, 203).

In a webpage entitled 'The Scientology Comparative Theology Page' authored by Perry Scott, and more precisely in its section entitled 'Hubbard maligns Christianity', reference is made to Hubbard's lecture 'Krakatoa and Beyond' (no. 10 in The Class VIII [Auditor's] Course, held on 3rd October 1968 aboard the ship Apollo), in which Scientology's founder stated:

Somebody somewhere on this planet, back about 600 BC found some pieces of R6. And I don't know how they found it, either by watching madmen or something, but since that time they have used it and it became what is known as Christianity. The man on the cross. There was no Christ. But the man on the cross is shown as Everyman. So of course each person seeing a crucified man, has an immediate feeling of sympathy for this man. Therefore you get many PCs who says [sic] they are Christ. Now, there's two reasons for that, one is the Roman Empire was prone to crucify people, so a person can have been crucified, but in R6 he is shown as crucified.

This can be heard in Hubbard's own voice through a link to an audio file reported on the same page. ' $\mathrm{R} 6$ ' is Hubbard's jargon for implants, and 'PC' is the abbreviation for 'pre-clear'. The same passage is also quoted in $L$. Ron Hubbard, Messiah or Madman? (Corydon and Hubbard Jr 1987, 362). It seems clear that Hubbard delivered the statement 'There was no Christ' as 
a punch line (he can even be heard taking a short pause and a puff on his cigarette before saying 'The man on the Cross'), intentionally speaking in a way that most Christians would find unsettling.

In the light of these last observations one can consider Scientology as characterised by a double standard where Christianity is concerned. To be sure, what we have just heard from Hubbard's narratives is scarcely reconcilable with Christian faith and teachings, not to mention its tone, which is incompatible with current interreligious dialogue etiquette. However, the problem of the double standard is not only Scientology's; nor does it necessarily whet the blades of those who maintain that Scientology is not religious. It is rather a shared problem of all religions. Claims of compatibility and observations concerning doctrinal analogies invariably emerge in a political context (lato sensu), in which diplomacy must be favoured above accurate analysis of the founders' doctrines (not to mention their private or theologically more marginal statements, as was the case in Hubbard's Apollo lecture). Indeed, when two religious messages confront each other, two 'truths' are inevitably at stake, even when one revelation is said to integrate rather than cancel out another. This is the case, for example, with Islam, whose similarities with and recognition of Christianity are often eagerly underscored in interreligious dialogue both by Muslims and Christians, whereas the Qur'ān explicitly denies both Jesus's divine nature and his supremely symbolic and theologically central death on the cross - statements that present a major theological challenge to interreligious tolerance and dialogue (Bigliardi 2014). In this sense Scientology's attitude is the rule rather than the exception.

\section{Scientology jargon}

In listing the factors that determine the survival of a new religious movement, Rodney Stark states that it should bear enough resemblances to extant ones so as not to be unsettling (Stark 1996). At the same time, a new religious movement should be different enough both to entice the curiosity of potential affiliates and to mark affiliates' identity. Both elements can be clearly detected in the language of Scientology. On the one hand, cultural continuity is mainly represented by the above-mentioned terminology and visual devices, which echo Christianity. On the other, Hubbard devised neologisms that define central concepts, roles, or practices in the church that create a special, dense Scientology jargon. They can be newly created or pre-existing terms to which Hubbard gave a new and specific meaning. 
'Engram', 'thetan', 'pre-clear', 'auditor', and 'auditing' are only a few examples among thousands.

This makes for a special feature of Hubbard's books, as well as of Scientology studies: the insistence and focus on terminology and on its correct understanding. Hubbard's books usually open with an 'Important Note', which reads:

In reading this book, be very certain you never go past a word you do not fully understand. The only reason a person gives up a study or becomes confused or unable to learn is because he or she has gone past a word that was not understood.

The confusion or inability to grasp or learn comes AFTER a word the person did not have defined and understood. It may not only be the new and unusual words you have to look up. Some commonly used words can often be misdefined and so cause confusion.

This datum about not going past an undefined word is the most important fact in the whole subject of study. Every subject you have taken up and abandoned had its words which you failed to get defined.

Therefore, in studying this book be very, very certain you never go past a word you do not fully understand. If the material becomes confusing or you can't seem to grasp it, there will be a word just earlier that you have not understood. Don't go any further, but go back to BEFORE you got into trouble, find the misunderstood word and get it defined.

Correspondingly, all Hubbard's books are integrated with a glossary and 'word clearing' (in itself a piece of Scientology jargon) broken into several passages and illustrated in detail, which is an important element of Scientology studies (CSI 2015).

\section{Hubbard and Scientology, 1965-7}

Scientology and the Bible was published in 1967. No period in the history of Scientology can be characterised as genuinely normal; and 1967 and the years prior to it were surely not.

In 1959 Hubbard had established the British head office of Scientology at Saint Hill Manor in West Sussex, where he had moved with his 
family in the spring. Here he was soon to be the subject of articles in local newspapers (Miller 1987 233ff.). In March 1961 he would launch a 'Saint Hill Special Briefing Course' for auditors to be trained under his guidance (Miller 1987, 242) and the manor would thus become the Mecca of Scientology. Bent Corydon remarks that ' [At Saint Hill Hubbard] was in touch with all Scientology activities around the world by a modern telex system that rivalled those of major corporations. Of the 300 to 400 crew members, some 20 worked long hours just manning the telexes and other communications systems between Hubbard and his world-wide organizations' (Corydon and Hubbard Jr 1987, 23).

This was the start of several years of prosperity for the movement. We read in Messiah or Madman: 'In the 1960s Scientology boomed. On five continents students of Scientology studied intently in "academies" at their "local Churches." People arrived in droves to take courses' (Corydon and Hubbard Jr 1987, 20). Scientology was going international, first reaching English-speaking countries, but at the same time attracting the attention of the authorities. In the Australian State of Victoria a Board of Inquiry was established in response to a Member of Parliament who had sought a ban on Scientology. The result was the above-mentioned Anderson Report. In the words of Russell Miller:

In October 1965, the Australian Board of Inquiry into Scientology published its report. Conducted by Kevin Anderson QC, the inquiry sat for 160 days, heard evidence from 151 witnesses and then savagely condemned every aspect of Scientology. No one needed to progress beyond the first paragraph to guess at what was to follow:

'There are some features of Scientology which are so ludicrous that there may be a tendency to regard Scientology as silly and its practitioners as harmless cranks. To do so would be gravely to misunderstand the tenor of the Board's conclusions. This Report should be read, it is submitted, with these prefatory observations constantly in mind. Scientology is evil; its techniques evil; its practice a serious threat to the community, medically, morally and socially; and its adherents sadly deluded and often mentally ill' (Miller 1987, 251).

Even Miller recognises that Anderson's tone was exaggerated: 'In his determination to undermine Scientology, Anderson completely ignored the fact that thousands of decent, honest, well-meaning people around the world believed themselves to be benefiting from the movement. To condemn the 
church as "evil" was to brand its followers as either evil or stupid or both - an undeserved imputation' (Miller 1987, 252). ${ }^{6}$

In October 1959 Hubbard had flown to Australia where '[a]t the Hubbard Communications Office in Spring Street, Melbourne, he was greeted by an ecstatic crowd of Scientologists who cheered noisily when he announced his belief that Australia would be the first "clear continent"' (Miller 1987, 236). The Report seriously questioned his sanity, describing him as delusional, megalomaniacal, and histrionic. He rebutted this immediately, calling it the outcome of a 'Kangaroo Court' that had already made its decision before even beginning the hearings, and making several unpleasant comments about the origins of the Australians and what might be expected from them. He also hinted that while serving in the Navy in the Second World War he had helped save Australia from the Japanese, and that the country was therefore ungrateful. Despite this, he stated, he would continue 'helping them' (Miller 1987, 253).

However, this inspired him to define a precise policy of how to react in such cases. In the words of Miller: 'The first step was to identify the antagonists, next investigate them "for felonies or worse" and then start feeding "lurid, blood sex crime actual evidence on the attackers" to the press. "Don't ever tamely submit to an investigation of us," he warned. "Make it rough, rough on attackers all the way"' (Miller 1987, 254). This was soon implemented when Great Britain followed the example of the State of Victoria. In December 1965 the Australian State of Victoria passed the Psychological Practices Act, outlawing Scientology. On 7th February 1966 Lord Balniel MP, at that time Chairman of the National Association for Mental Health, asked the Minister of Health to initiate an inquiry into Scientology in Britain, and Hubbard hired a private detective to start an investigation (Miller 1987, 253254). Meanwhile, Scientology had experienced major problems in the US, the FDA having raided its Washington headquarters in January 1961 and

6 Doherty 2015 presents a meticulous reconstruction of the events leading up to and following the Anderson Report, mainly based on previously unexplored government material. Concerning the general tone and content of the report, Doherty remarks: '[it] delved heavily into the scientific and medical claims which Hubbard had made in various writings and into the technical efficacy of the E-Meter, but [it] gave short shrift to the claims made by everyday Scientologists about the alleged benefits they received from their involvement' (Doherty 2015, 24-25); 'Despite its hyperbole, the report was in certain aspects exhaustive and featured extensive analysis of much of Hubbard's written work, as well as details about the financial operations, organization, and alleged harm caused by the group to family life and community morals. However, the later charge that the report bore the imprint of Anderson's own conservative morality, and the repugnance with which he viewed what he called "Hubbard's morbid preoccupation with perversion," is well founded' (Doherty 2015, 26). 
confiscated books and E-Meters (Miller 1987, 247). This latter event would result in a long series of court battles in the US (Urban 2011, 63).

In March 1966 Hubbard established the Guardian's Office, whose function was to protect the organisation, gathering information about agencies and individuals who might constitute a threat to the church. It was headed by Hubbard's third wife, Mary Sue (1931-2002).

Miller also reports that, in an attempt to restore Scientologists' morale, Hubbard started circulating the news that John McMaster, a South African Scientologist who started auditing after an operation for his stomach cancer, was the world's first clear after passing an E-Meter test on 8th March 1966 (Miller 1987, 254f.). McMaster would leave the church only a few years later, having been designated a major spokesperson and even 'Pope' of Scientology, which attracted considerable attention and made Hubbard envious (Miller 1987, 273; see also Corydon and Hubbard Jr 1987, 25f.; 181; 316f.; Ortega 2015).

In 1966 Hubbard issued a statement in which he renounced his title of 'Doctor' (which had, in fact, been issued by a diploma mill), a protest against all those who, endowed with PhDs, had harmed humanity (Miller 1987, 255). He then headed for Rhodesia, a British Territory in Southern Africa (now Zimbabwe), where Prime Minister Ian Smith and his cabinet had issued a Unilateral Declaration of Independence on 11th November 1965. Hubbard, who had already lectured to Scientologists in Cape Town and Johannesburg in October and November 1960 and in Johannesburg in January 1961 (Miller 1987, 242), tried to exploit the politically troubled situation by presenting himself as an American millionaire who could help the state's finances. He developed links with prominent citizens and politicians and even penned a draft for a new constitution, which he submitted to the Prime Minister's office, receiving a diplomatic but non-committal response. It is even reported that Hubbard identified with Cecil John Rhodes (1853-1902), the British millionaire and politician who was the territory's eponymous founder. It is likely that his controversial status, grandeur and success inspired Hubbard. However, Hubbard was forced to leave the country after his application for a temporary residence extension failed. He delivered a speech (filmed by Rhodesian television) on 15th July, and flew back to England, where he received an enthusiastic welcome. The Rhodesian enterprise resulted in a major financial loss (Miller 1987, 256-260).

Aware that trouble was also mounting in the US, where the Internal Revenue Service had started questioning Scientology's tax-free status, Hubbard formulated a new and secret plan. In September 1966 he formally stepped 
down as Scientology's president, claiming that the church was sufficiently organised to survive without him. On 12th August 1967 he launched the Sea Org. In the words of Miller: '[Hubbard] raised a private navy, appointed himself Commodore, donned a dashing uniform of his own design and set forth on an extraordinary odyssey, leading a fleet of ships across the oceans variously pursued by the CIA, the FBI, the international press and a miscellany of suspicious government and maritime agencies' (Miller 1987, 263).

The Sea Org initially comprised four ships: the Diana, the Athena, the Apollo, and the Excalibur. During his eight-year 'extraordinary odyssey' Hubbard was to elaborate new Scientology teachings (we have already seen that a lecture touching upon Jesus Christ was delivered on board the Apollo). The daily routine and Hubbard's on-board behaviour have been described by former members as characterised by blatant disrespect for basic human rights, with onerous chores and food deprivation for Scientologists deemed guilty of various failures.

Based on land, the Sea Org remains a core, upper-level institution of Scientology whose members, according to its entry on the official web site, 'work long hours and live communally with housing, meals, uniforms, medical and dental care, transport and all expenses associated with their duties provided by the Church. They also receive an allowance to purchase personal items, as all of their other expenses are fully covered by the Church' (Scientology 2015c; see also Melton 2001).

\section{Scientology and the Bible}

Scientology and the Bible is a fifty-page pamphlet (four supplementary pages contain the customary Glossary of Dianetics and Scientology terms). The cover displays a white drawing on a black background of a long-haired, bearded face with an enigmatic expression. The expression might be of slight suffering or compassion. It might be interpreted as a portrait of a prophet, or as a representation of a fatherly God (the white hair makes it unlikely that it represents Jesus Christ). Under the drawing is the motto 'Scientology is here to rescue you'. There is a biblical verse on the title page, Proverbs 21:30: 'There is no wisdom nor understanding nor counsel against the Lord' (translations from the Authorised Version).

The title is repeated on the second page, where there is also an interesting subtitle that defines the pamphlet: 'A manifest paralleling the discoveries of Scientology by L. Ron Hubbard with the Holy Scriptures'. This page also reports that it was compiled by Catherine Biggs, Colin Chalmers, Margaret 
Chalmers, Doreen Elton, Gladys Goodyer, Catherine Steele, and Dorothy Penberthy, and that the booklet was published by the Department of Publications World Wide.

On the third page there is a quotation from a 1964 text by Mary Sue Hubbard ('Supplement to "Communication"') under a heading in capital letters: 'Scientology is a religion'. In this short paragraph we read that

Scientology is a religion in the oldest sense of the word, a study of wisdom. Scientology is a study of man as a spirit, in his relationship to life and the physical universe. It is non-denominational. By this is meant that Scientology is open to people of all religious beliefs and in no way tries to persuade a person from his religion, but assists him to better understand that he is a spiritual being...

The fourth page provides the reader with some further insights into the booklet's production. Here we read that the Department of Publications World Wide is a branch of the Church of Scientology of California, registered in England at Saint Hill. The Copyright is by L. Ron Hubbard, and the booklet was printed by Southern Publishing in Brighton.

More importantly, there is also a dedication: 'IN MEMORIAM. To Katie Steele, who in August 8, 1966, left her body for life elsewhere, our love and gratitude for having concluded and piloted the completion of this pamphlet.' A note with an asterisk specifies that Steele was 'Killed by medical doctors administering an incorrect drug in Melbourne, Victoria, Australia, 1966.'

The fifth page reports a short version of the usual instructions about clearing words while studying a text. The sixth contains a short foreword that gives further clues as to the booklet's production: 'The relationships drawn between [Hubbard's works quoted] are those discovered by the compilers. The reader making his own studies will undoubtedly find many more.'

The text itself starts on page eight. Each page is divided into two columns. The one on the left prints passages of Hubbard's works. The one on the right prints passages from the Holy Scriptures. A section towards the end of the booklet displays the same structure but is entitled 'Similarities between the discoveries of Scientology by L. Ron Hubbard and the aims and goals of the fathers of the Church'. The fathers of the church referred to are Saint Augustine (354-430 CE), Leo the Great (390-461 CE), and Saint Thomas Aquinas (1225-74 CE). Their works referred to are: Augustine's Confessions (398 CE), Sermon on Passion Sunday (undated), On Christian Doctrine (397 $\mathrm{CE})$, The City of God (426 CE); Leo the Great's Sermon on the $4^{\text {th }}$ Sunday in Lent 
(455 CE); and Thomas's Summa Contra Gentiles (1270-3 CE). However, in the column on the right a quotation from the Proslogion (1077-8 CE) of Anselm (1033-109 CE) is also printed. Anselm's name is mentioned here, although it does not occur in the section's title. On page 48 the column on the right is abruptly headed 'Anglican Church' (without further explanation) and the texts quoted are the Catechism, Articles of Religion, the Apostles' Creed, the Athanasian Creed, and further quotations from the Holy Scriptures.

Hubbard's works quoted in the first column include Science of Survival (1951), 'The Creation of Human Ability' (1954), a piece for the magazine The Auditor (1964) and one from 'Professional Auditor's Bulletin' (1965), as well as numerous and extensive quotations from unspecified material compiled between 1923 and 1953. Hubbard's texts touch on both the theoretical tenets of Dianetics and Scientology, and the ethics of the auditors and of Scientologists in general.

The parallels are presented as self-evident. Indeed, there are occasional terminological connections between Hubbard's passage and those from the Holy Scriptures. For example: '11. Never get angry with a pre-clear' is paired with Proverbs 15: 'A soft answer turneth away wrath. But grievous words stir up anger' (p. 11). Sometimes the connection is vaguer. For example, the passage '18. Estimate the current case of your pre-clear with reality and do not process another imagined case' is paired with Proverbs 20, 'Counsel in the heart of man is like deep water; but a man of understanding will draw it out'. More often the connection is difficult to make, especially when Hubbard's passages touching upon universe and knowledge are paired with scriptural ones. For example, 'Bringing the static to create a perfect duplicate causes the vanishment of any existence or part thereof' is paired with Psalm 32, which starts with 'Blessed is he whose transgression is forgiven, whose sin is covered' (p. 17). Or again, axiom 26, 'Reality is the agreedupon apparency of existence' is paired with Proverbs 23 'Remove not the old landmark; (and enter not into the fields of the fatherless)'.

It should be noted, however, that the passages are not always paired one to one. Sometimes a long quotation in the left column is paired with a short one in the right, and vice versa. In two cases lengthy quotations in the right column, from Proverbs, Ruth, Psalms, Ecclesiastes, and the Gospels, are presented without being paired with any quotation from Hubbard, but we only read, in the corresponding left-hand column, the headings 'On the Scientology Ethics System' (p. 42), 'On receiving payment or emolument for such great service and benefit' (p. 43) and 'On disseminating Scientology' (p. 44). The scriptural passages are sometimes repeated, i.e. identical ones 
are paired with different passages from Hubbard's works.

Occasionally, the column on the right presents small pieces of exegesis. For example, on page 13, after a quotation from Matthew 12, 'For by thy words thou shall be justified, and by thy words thou shall be condemned', we read: 'justified = cleared'. On page 30, in the right-hand column, we read the comment: 'People who have practiced listening - auditing - 1. Jesus 2. Solomon 3. Isaiah (possibly others)'.

There is scarce information about the authors or compilers in extant Scientology sources. In a 1967 issue of The Auditor Worldwide Katie Steele is included among the 'deaths' under the heading 'Vital statistics' (p. 7). No date is given. It is revealed that she was an HPA, a Hubbard Professional Auditor, and she is described as 'an early old-time Scientologist who did the major work on the drawing up of parallels between Scientology as a religion and other major religions, to be published soon at Saint Hill'. ${ }^{7}$

Indeed, Scientology and the Bible is not the subject of much serious discussion or reference on the internet. The only discussion of any depth is that of Joseph Martin Hopkins, who, although writing as an academic, is very critical. Concerning the booklet he writes: 'Forty-four pages of the booklet Scientology and the Bible are set up in parallel columns with this objective. That often there is not the remotest correspondence between the Hubbard passages and the accompanying biblical quotations.' He also criticises Scientology's compatibility with Christianity as follows: 'Absent from Scientology practice are the basic constituents of the Christian religion: reverent faith, prayer, worship, reading of and preaching from the Christian Scriptures,

7 Steele was probably an Australian Scientologist who was either a student or employed at Saint Hill for some time: one can infer from books such as Messiah or Madman? that such stays were far from infrequent. The ex-Scientologist 'Don Carlo' (who prefers to remain anonymous) has provided me through the web site Operation Clambake's discussion forum with the results of the research he expressly (and generously) undertook after he was asked about his opinion of the booklet's authorship, but the trails on genealogy UK and Australian websites proved somewhat weak. 'Familysearch has: Name Dorothy G Penberthy Event Type Marriage Registration Quarter Jul-Aug-Sep Registration Year 1978 Event Place Crawley, Sussex, England Spouse Name Thomas B Minchin https://familysearch.org/ark:/61903/1:1:QVX7-XPZV; Googling 'Minchin' + 'Scientology' gave many hits, including the "Church's Australian vicepresident the Reverend T. B. Minchin" fighting for religious status in 1972, at http://www. suburbia.net/ fun/scn/presst ... 0829AU.HTM There are a lot of Dorothy Minchin names in Australia and the UK. The trail gets harder after this' (private message, 3rd October 2015); 'Colin Chalmers was an early Clear in Melbourne, Australia, but like the others, disappears from Scientology news reports after this book. I agree that nobody is supposed to be an official writer in Scientology except L. Ron. Hubbard or HIS ghostwriters. They likely got criticized and quit or were expelled. They would likely be at least in their seventies, now, if they are still alive' (private message, 3rd October 2015). 
observance of the sacraments as instituted and explained in the New Testament' (Hopkins 1969, part 2).

\section{Informants}

Questioned about the booklet, its authors, and circulation, William Burke, an ex-Scientologist who runs the blog Ask the Scientologist, explained:

Around that time, there were a few secondary books being produced by Scientologists. Ruth Minshull wrote a number of them, 'Miracles for Breakfast', 'How to Choose Your People', 'Ups \& Downs'. Peter Gillham wrote 'Fundamentals of Success'. 'Scientology and the Bible' was written around the same time. I think there might have been others. Initially they were welcomed and some even showed up in some Scientology bookstores. Some felt they were 'easier to read' than Hubbard's writings. But then Hubbard decided they were 'squirrel' [deviant] and all non-Hubbard books were banned, at least from the bookstores. I believe the authors were called into 'Ethics' [punished] and ... discouraged from selling those books or writing any more (private communication, 3rd October 2015).

He continued:

[The booklet] was authorized for a short time, and a number of other books were also officially authorized at that time, as I mentioned. There was even a standard line to get such 'secondary' books approved. ('Secondary' meaning they were not authored by Hubbard). That didn't last too long. Initially these 'secondary' books/booklets were accepted by Scientology and were even sold in the church bookstores. Some of these books were even considered by many Scientologists as being better for new publics to get them interested in Scientology. After a few years, Hubbard noticed this trend, non-Hubbard books being preferred over his books. This did not sit well with Hubbard. Initially, he just forbade church bookstores from carrying such books but then he revoked all such authorizations, which effectively killed all such activities. The only approved books were his books. I don't know that 'Scientology and the Bible' was ever very popular. It was considered more of a 'PR' endeavor, trying to make Scientology appear 'normal' and even 'compatible' with the Bible (private communication, 11th October 2015). 
Jefferson Hawkins, an ex-Scientologist who runs the blog Leaving Scientology, explained:

I don't know much about it. I recall the booklet, and we had some copies of it at Pubs Denmark in 1968, so it was 'authorized' in some way. I knew Dorothy Penberthy. Her husband Barry worked at Pubs in the E-Meter area, repairing and restocking meters. They were Aussies. The name Margaret Chalmers rings a bell, although I didn't know her. The other names are not familiar to me (private communication, 17th October 2015).

Similar questions were posed to a lifetime Scientologist in Australia, wellacquainted with the local 'old-guard'. After some investigation following our initial contact my informant explained:

I have found out [...] that Margaret Chalmers is still alive and working for the Church overseas, so I am sending her an email to ask if she can give me some information to provide to you. All the others have passed away. She is our last link to provide specifics. [...]. I have found out that Katie Steele was the mother of Catherine Steele, one of the authors. The authors were all from Melbourne, Australia and wrote in [sic] while there. The Church had just been banned in 1965, so this was two years after that. The Church had moved underground as it was illegal to practice Scientology or use the word, but it had never stopped and was spread around Melbourne in various houses. Quite a few Melbourne Scientologists had moved to Sydney where there was no barrier to being a Scientologist and some went to Saint Hill, England (private communication, 13th March 2016).

Some more investigation followed and the informant eventually wrote:

I heard back from the remaining person alive (Margaret Chalmers) who worked on this research. She said that she did the research but was not aware it had been published and had not ever seen the published booklet. She couldn't enlighten me on the booklet otherwise. I asked some others and they had seen the booklet in the late 1960s, but only in passing like 'Oh yeah, I recall that booklet,' but not much else. It was some time ago and a lot of people from that time have passed away, so the story is lost to a large extent. It was only published that one time and there are some rare copies around. Margaret wasn't aware of the circumstances of the death of Katie Steele so could not shed any light on that entry in the booklet. She 
had already left Melbourne for England. So I have hit a dead end on that one. Her recollection of the time was in 1964 she and the other Melbourne Scientologists compiled the passages. There was at that time misunderstanding about Scientology in Melbourne. Scientology, quite unfairly, was seen to challenge the 'status quo.' A religious philosophy that was more akin to Eastern faiths was intolerable in a strongly Christian community that was struggling as a whole with the rapid change that was taking place in the $60 \mathrm{~s}$ and the emergence of new ideas. It was a volatile time in general (private communication, 24th March 2016).

\section{Discussion}

The booklet Scientology and the Bible has some features seemingly unparalleled elsewhere. Scientology publications not authored by Hubbard are rare and group authorship for a work exploring theological, comparative matters is unique (cf. Frenschskowski 1999, §4). The title, further elaborated by the term 'manifest', is enticing and allows (or rather allowed, if the text was eventually banned) any Scientologist who was aware of its existence in reference to such a work to claim that the analogies between Christianity and Hubbard's religion had been successfully explored. ${ }^{8}$ The book's small dimensions probably made for cheap production and easy distribution, so one can suppose that the pamphlet could be used for proselytism.

However, the text is hopelessly univocal and substantially incomprehensible to anyone of a Christian background and without any knowledge of Scientology. It seems the result of the reflection of someone who, although possibly from a Christian background, had been more trained in Scientology's practice of 'word clearing' and in the reading of Hubbard's work than in the exercise of engaging with the (Christian) counterpart's texts and mindset. Its use of columns was perhaps suggested by the synoptic gospels, but it is also the most intuitive one for anyone who wants to (literally) pair texts. Indeed, the booklet appears weak even if one tries to read it as a mere introduction to Scientology's teaching, which supposedly a Christian reader would be unable to master. Fragments of Hubbard's work are presented completely without context, notwithstanding the presence of the final, customary Glossary. No analytical explanation of Dianetics/Scientology is presented, not even in sketchy form, and the parallels between Hubbard's texts and biblical fragments are often completely opaque. Quite apart from

8 It is uncertain whether the term 'manifest' is used as 'manifesto' or as a synonym of 'list' (a definition of 'manifest' being a document listing the cargo, passengers and crew of a ship). 
the fact that the booklet's project stemmed from a genuine desire to show analogies between Scientology and Christianity or that it was only written in the interest of public relations, it is simply inefficacious. Jesus is not a central topic, some correspondences are left completely obscure, and even the choice of specific Christian authors is left unexplained. In this regard we should also observe, however, that references to Christ are so scant that the resulting effect is almost neutral or harmless, unlike the innuendo of the above-mentioned Apollo lecture.

Reading Scientology and the Bible is like being confronted with the outcome of an autonomous rumination penned quite spontaneously and hastily printed, a tip of an iceberg whose supporting and greater part remains under the surface. Anybody approaching this booklet in the hope of finding inspiring theology, even embryonic or simplistic, would be disappointed. It is an expression of individual, unilateral conviction, not a real attempt to build a bridge between different systems of belief. At the same time, we must recognise that the choice of Christian authors does display some degree of knowledge or sophistication, unless we believe that they were randomly selected from a handbook or digest of Christian thinkers (we should remark that interestingly, and in latent tension with the reference to Anglicanism, Leo the Great was also a Catholic Pope). The booklet's fragmentary character might be explained by the absence of a genuine intention to elaborate a text displaying structure and some depth, or perhaps by the compilers' lack of writing and critical skills and editorial experience.

The collective character of the enterprise may also contribute to an explanation of such features. It is as if Scientology and the Bible was an extemporary collection or patchwork of individual reflections on the same texts that were assigned to different Scientologists, upon which they reflected in the light of their knowledge of Scientology's teaching to eventually discuss them briefly and glue them together in a publication that was not further coordinated or edited. I hypothesise that the texts assigned to the different compilers were identical because of the repetition in the column of biblical materials. Thus, even if this text had not been eventually forbidden by Hubbard, it could have hardly been of use in any interreligious debate or reflection.

However, this booklet was published and it did circulate as official church material. How can we explain this? Having established that the booklet fails to meet the expectations it raises and that it is theologically weak, we may still ask: what was its Sitz im Leben, that is, its precise function when it was released? It is possible that the death of the mother of one of the compilers 
was a decisive factor in its publication. ${ }^{9}$ There was probably a need to honour Katie Steele and the very fact that her death happened under circumstances that could be presented as confirming Scientology's antagonism towards, and criticism of, the medical establishment may have prompted the publication. However, it may also seem unlikely that anybody would embark on such a project, albeit amateurishly, without harbouring from the very beginning the intention of publishing its outcome. Indeed, in 1966 Scientology needed to reaffirm its ties with its surrounding culture, especially in an Anglican context. The case of Katie Steele, whatever the precise events were, happened in a country where Scientology was at the centre of a virulent debate. Finally, Hubbard had just left Saint Hill and was fully absorbed in Sea Org matters. His physical absence probably entailed a relaxation in the chain of command, thus allowing the authorisation of a publication like Scientology and the Bible.

\section{Conclusion}

Scientology and the Bible's overall theological and communicative weakness alone cannot have been a decisive factor in its prohibition or disappearance. Even in the absence of confirmation that the booklet was formally forbidden by Hubbard we can accept Jefferson Hawkins's reconstruction as highly plausible. As we have seen, from the earliest period of Dianetics Hubbard was struggling with internal 'scientific' deviations. Where Scientology's teaching was concerned, Hubbard was a 'one-man lab' and enterprise - or at least he wanted to be treated and perceived as such. He was likely to view any creative elaboration drawing on his teachings as a blow to his ego, besides constituting a dangerous precedent of intra-Scientology creativity (as the case of McMaster indirectly shows). Indeed, the problem was not that somebody else was helping Hubbard to elaborate his own ideas. This was actually a common practice, especially in the magazine Advance!, which directly addressed the continuity of Scientology with other religions (see Bigliardi 2015). But Advance! was strictly supervised by Hubbard, its real authors were scarcely credited, and it was not the forum in which major 'discoveries' were announced. The major problem with Scientology and the Bible was that somebody else's authorship was clearly recognisable. Although there might have been a phase in which 'satellite works' were tolerated and perhaps even encouraged, it was only a matter of time that

9 Before receiving this information from the Australian Scientologist, I was inclined to think that Katie and Catherine Steele were one and the same person. 
any publication that threatened Hubbard's centrality (in his eyes as well as the eyes of Scientologists) would be forbidden.

It should be emphasised that the idea that a work such as Scientology and the Bible was likely to be perceived by Scientology's founder as a threat is compatible both with the thesis of his sincerity and that which suggests he was opportunistically introducing new teachings. In this sense this interpretation should not be automatically thought of as instrumental to a more general interpretation of Hubbard's doctrinal changes: even an inspired prophet (which, as we have seen, was technically not the case with Hubbard's unfolding message) is interested in maintaining the revelation intact and incorrupt, and any external addition and discussion while the prophet is still alive can be perceived by the prophet as unnecessary and centrality-threatening.

If one considers internal Scientology dynamics, it appears quite natural that Scientology and the Bible had a short life. Over time PR with other religions (as well as with institutions by which Scientologists wanted to be perceived as a religious community engaged in a dialogue with other religious communities) was to become an increasingly important topic for Scientology. However, its publication and perceived usefulness was the result of a transient state of affairs that would rapidly disappear. Thus, under the ambitious title Scientology and the Bible all we are left with today is an anomalous piece of Scientology ephemera.

Stefano Bigliardi is Assistant Professor of Philosophy, Al Akhawayn University in Ifrane. E-mail: S.Bigliardi@aui.ma 
References

(All websites were accessed for a final check on October 30, 2015)

Scientology/Hubbard literature

The Auditor Worldwide. The Journal of Scientology (ed. L. Ron Hubbard)

1967 Vital Statistics - Deaths. No 9, 7. <http://www.iapsop.com/archive/ materials/auditor/auditor_19.pdf>

Briggs, Catherine \& Colin Chalmers, Margaret Chalmers, Doreen Elton, Gladys Goodyer, Catherine Steele, Dorothy Penberthy

1967 Scientology and the Bible. A Manifest Paralleling the Discoveries of Scientology by L. Ron Hubbard with the Holy Scriptures. Saint Hill (Sussex, GB): The Department of Publications World Wide.

\section{Church of Scientology International [CSI]}

1998 Scientology. Theory and Practice of a Contemporary Religion. Los Angeles: Bridge Publications, Inc.

2015 Clearing Words - The Scientology Handbook. Tools for Life. <http://www. scientologyhandbook.org/study/chapter1.htm>

\section{Hubbard, Lafayette Ronald}

1950a Dianetics: The Evolution of a Science. Astounding Science Fiction 45 (3), 43-87.

1950b Dianetics. The Modern Science of Mental Health. New York: Paperback Library.

\section{Scientology}

2015a Does Scientology Have a Concept of God? <http://www.scientology. org/faq/scientology-beliefs/what-is-the-concept-of-god-in-scientology.html>

2015b What is Scientology's View of Moses, Jesus, Muhammad, the Buddha, and Other Religious Figures of the Past? <http://www.scientologynews.org/faq/scientology-view-moses-jesus-mihammad-buddha. html>

2015c What is the Sea Organization? <http://www.scientology.org/faq/ church-management/what-is-the-sea-organization.html> 
Scholarly texts

\section{Bigliardi, Stefano}

2015 What Would Ron Choose from the Islamic Basket? Notes on Scientology's Construction of Islam. Temenos. Nordic Journal of Comparative Religion 51-1, 95-121.

2014 Thinking Muhammad Legenhausen's Non-Reductive Pluralism Through: Some Reflections about its Implications. International Journal of Islamic Thought 6, 71-8.

\section{Dericquebourg, Régis}

2009 How Should We Regard the Religious Ceremonies of the Church of Scientology? James R. Lewis (ed), Scientology, 165-82. New York and Oxford: Oxford University Press.

\section{Doherty, Bernard}

2015 Colonial Justice or a Kangaroo Court? Public Controversy and the Church of Scientology in 1960s Australia. Alternative Spirituality and Religion Review 6:1, 9-49.

\section{Frenschkowski, Marco}

1999 L. Ron Hubbard and Scientology: An Annotated Bibliographical Survey of Primary and Selected Secondary Literature. Marburg Journal of Religion 4 (1), 1-24 URL: http://www.solitarytrees.net/pubs/li-fren. htm

\section{Harley, Gail M. \& John Kieffer}

2009 The Development and Reality of Auditing. James R. Lewis (ed), Scientology, 183-205. New York and Oxford: Oxford University Press.

\section{Kent, Stephen A., \& Terra A. Manca}

2014 A War over Mental Health Professionalism: Scientology versus Psychiatry. Mental Health, Religion E Culture 17(1), 1-23.

\section{Melton, J. Gordon}

2000 The Church of Scientology. Turin, Italy; Elle Di Ci.

2001 A Contemporary Ordered Religious Community: The Sea Organization. Paper presented at the 2001 CESNUR Conference in London. <http://www.cesnur.org/2001/london2001/melton.htm>

\section{Stark, Rodney}

1996 Why Religious Movements Succeed or Fail: A Revised General Model. Journal of Contemporary Religion, 11(2); 133-46. <http://www.premrawat-bio.org/academic/stark1996.html>

Urban, Hugh B.

2011 The Church of Scientology: A History of a New Religion. Princeton, NJ: Princeton University Press. 
Wallis, Roy

1976 The Road to Total Freedom: A Sociological Analysis of Scientology. London: Heinemann.

Secondary literature about Hubbard and Scientology

Atack, Jon

1990 A Piece of Blue Sky: Scientology, Dianetics and L. Ron Hubbard Exposed. New York, NY: Carol Pub. Group.

\section{Corydon, Bent \& L. Ron Hubbard Jr.}

1987 L. Ron Hubbard: Messiah or Madman? Secaucus, N.J.: L. Stuart.

\section{Hopkins, Joseph Martin}

Scientology: Religion or Racket? - Christianity Today 7th November 1969: 6-9; 21st November 1969: 10-13. < http://www.ezlink.com/ perry/ CoS/Theology/racket-1.htm and http://www.ezlink.com/ perry/CoS/ Theology/racket-2.htm>

\section{Miller, Russell}

1987 Bare-faced Messiah: The True Story of L. Ron Hubbard. London: M. Joseph.

\section{Ortega, Tony}

2014 UP THE BRIDGE: We finally reach 'OT 8' - but was its first version really a hoax? - The Underground Bunker <http://tonyortega. org/2014/06/24/up-the-bridge-we-finally-reach-ot-8-but-was-its-firstversion-really-a-hoax/>

2015 Scientology's first 'Clear': L. Ron Hubbard intended to return as his daughter Diana's son. The Underground Bunker < http://tonyortega. org/2015/01/20/scientologys-first-clear-1-ron-hubbard-intended-toreturn-as-his-daughter-dianas-son/>

\section{Scott, Perry}

1998 The Scientology Comparative Theology Page. <http://www.sweenytod.com/cos//Theology/Theology/>

\section{State of Victoria}

1965 Report of the Board of Inquiry into Scientology. <http://www.xenu.net/ archive/audit/andrhome.html> 
Web pages

Operation Clambake. Undressing the Church of Scientology since $1996<\mathrm{http}: / /$ www.xenu.net/>

Ask the Scientologist <https://therealaskthescientologist.wordpress.com/>

Leaving Scientology<https://leavingscientology.wordpress.com/> 